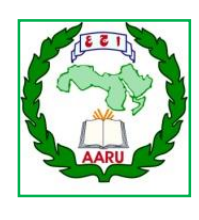

$14^{\text {th }}$ Conf. Agric. Develop. Res., Fac. of Agric., Ain Shams Univ., March, 2019, Cairo, Egypt

Special Issue, 27(1), 347 - 355, 2019

Website: http://strategy-plan.asu.edu.eg/AUJASCI/

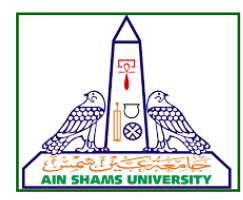

\title{
IN VITRO EVALUATION OF ENSILING AND /OR EXOGENOUS FIBRO- LYTIC ENZYME SUPPLEMENTATION OF DATE PRESS CAKE
}

[32]

\author{
Fahmy $^{1 *}$, M., Morsy ${ }^{1}$, T.A., Gado ${ }^{2}$, H.M., Matloup ${ }^{1}$, O.H., Kholif ${ }^{1}$, S.M. \\ and El-Bordiny ${ }^{2}$, N.E.
}

1. Dairy Sciences Dept., National Research Centre, Dokki, Giza, 12311, Egypt

2. Animal Production Dept., Fac. of Agric., Ain Shams Univ., P.O. Box 68 Hadayek Shoubra, 11241, Cairo, Egypt

*Corresponding author: fahmymahmoud2@gamil.com

Received 12 December, 2018, $\quad$ Accepted 22 January, 2019

\begin{abstract}
This study was conducted to evaluate the effect of ensiling and /or exogenous fibrolytic enzyme supplementation date press cake using in vitro batch culture technique. Untreated date press cake (DPC) and ensiled DPC with exogenous fibrolytic enzymes (ZAD1 and ZAD2) and with or without adding urea compared to corn grains were in vitro evaluated using batch culture technique. DM, NDF and ADF degradation and total gas production as well as fermentation parameters of the incubated samples were determined after $24 \mathrm{~h}$ of fermentation. Total VFAs, proportions are not affected $(P>$ $0.05)$ by any of the treatments. However, value of ammonia concentration was higher $(P<0.05)$ with $\mathrm{ZAD} 2+\mathrm{U}$ group and urea group than date press cake (DPC). The $\mathrm{pH}$ value was highest $(\mathrm{P}>0.05)$ with the ensiling treatments. There were no significant differences in the values of DMD and OMD between the different treatments. But, the values of NDFD and ADFD were increased $(P<0.05)$ in the corn group. Total gas production had no difference $(P>0.05)$ between the corn grain and the DPC without any treatments. While, values of metabolizable protein (MP) and efficiency of microbial biomass production $(E M P)$ were increased $(p<0.05)$ with DPC compared to corn grains. There was no significant difference in the rumen activity when using date press cake (DPC) or corn grains. Moreover, the ensiling process did not cause a clear improvement in rumen fermentation.
\end{abstract}

Keywords: Date press cake; In-vitro Ruminal Fermentation; Gas production.

\section{INTRODUCTION}

Corn is one of the most important grain crops in the world. About $52 \%$ of the corn production is used for animal feed, while, $37 \%$ is consumed in the production ethanol plants, and $11 \%$ go to the food industries.Because of the shortage and the high price of yellow corn grains, one of the alternatives to solve this problem is using nonconventional ingredients as a partial replacement of corn grains in ruminant rations.

On the other side, wasted date and date byproducts are promising as a non-traditional carbohydrate sources in animal nutrition. When dates undergo extraction for syrup or alcohol production, the extraction yields a by-product (press cake) which is made of exhausted date flesh and residual sugars, with or without pits. Press cake is a high moisture product that does not store easily and may become a disposal problem (Barreveld, 1993).

Fresh press cake contains about $70 \%$ water. It may contain or not pits, so its crude fiber content varies from 9 to $22 \% \mathrm{DM}$. Like the fruit, its protein content is rather low (5-8 \% DM). Sugar content depends on the extraction rate and can be as low as $15 \% \mathrm{DM}$. Research on date press cake is very limited (Barreveld, 1993). Due to their high carbohydrate content and relatively low fiber, press cake 
has a high energy value, as high as that cereal grains such as barley (Boudechiche et al 2010).

The objective of this in vitro study was to compare the effect of corn, date press cake alone (DPC) and date press cake treated with some treatments on rumen degradation and fermentation activity.

\section{MATERIAL AND METHODS}

\section{The study Materials}

Date Press Cake (DPC): It is the exhausted date fresh with some residual sugar with or without the pits incorporated, depending on the type of extraction.

\section{Exogenous fibrolytic enzyme.}

$\mathrm{ZAD}{ }^{\circledR}(\mathrm{ENZ})$ is a commercial product "liquid multi enzyme feed additive produced from Ruminococcus flavefaciens". Authorized by the Academy of Scientific Research and Technology in Egypt (Patent No.: 24551, Cairo, Egypt). ZAD1 is Probiotic-anaerobic bacterial and exogenous enzymes (Ruminococcus Bacteria with clove essential oil). ZAD2 is probiotic-anaerobic bacterial and exogenous enzymes. (Ruminococcus Bacteria without clove essential oil).

\section{Experimental treatments}

Date press cake (DPC) was ensiled with Zad1, Zad2 (2 $\mathrm{ml} / \mathrm{kg}$ dry matter) and with or without urea (1.5\% / kg dry matter) (3 jars per each treatment) and stored for 45 days, the experimental treatments were corn grains, DPC without treatment and five supplemented treatments ( DPC supplemented with Zad1, DPC supplemented with Zad2, DPC supplemented with Zad1+ $1.5 \%$ urea, DPC supplemented with Zad2+ $1.5 \%$ urea and DPC supplemented with urea) and five ensiled treatments (DPC ensiled with Zad1, DPC ensiled with Zad2, DPC ensiled with Zad1+ $1.5 \%$ urea, DPC ensiled with Zad2+ $1.5 \%$ urea and DPC ensiled with urea).

\section{In vitro gas production technique}

Two days before beginning of the experiment, $400 \pm 4 \mathrm{mg}$ of sample for each treatment was weighed into $125 \mathrm{~mL}$ glass bottles. These bottles have a total volume of $125 \pm 2 \mathrm{~mL}$. A buffer solution was prepared before addition of rumen fluid as described by (Szumacher-Strabel et al 2002) and flushed continuously with $\mathrm{CO}_{2}$ at $39^{\circ} \mathrm{C}$ during sample inoculation. Rumen fluid was obtained from slaughter house and it was collected from sheep. The collected rumen fluid was mixed into a bottle (1L) with an $\mathrm{O}_{2}$-free headspace and immediately transported to laboratory at $39^{\circ} \mathrm{C}$. Upon arrival at the laboratory, the rumen fluid was filtered through four layers of cheesecloth to eliminate large feed particles. The buffer solution was added to rumen fluid at ratio $4: 1$. Forty $\mathrm{mL}$ of this inoculum was added to each bottle, then the headspace of each bottle was flushed with $\mathrm{CO} 2$, and closed. The initial $\mathrm{pH}$ of the inoculums was from 6.8-6.9. Triplicates of each sample were used for each treatment.

\section{Degradability}

Dry matter degradability (\% dDM) was calculated as the (difference between the sample DM content and that in the residual after $24 \mathrm{~h}$ incubation / sample DM content * 100). NDF and ADF of the residuals after fermentation were analyzed with the same methods used for feed ingredient analysis. Degradability of NDF, ADF, cellulose and hemi were calculated as (difference between the content in the sample before and after incubation / content in the sample before incubation *100).

\section{Total gas production}

After $24 \mathrm{~h}$ of samples incubation, the total gas production was estimated by the displacement of syringe piston, which was connected to the serum flasks. The gas produced due to fermentation of substrate was calculated by subtracting gas produced in blank vessels (without substrate) from total gas produced in the vessels containing buffered rumen fluid and substrate.

\section{Calculation}

Metabolizable energy (ME, Mcal/kg DM), In vitro organic matter digestibility (OMD, \%) were estimated according to (Menke and Steingass, 1988), (SCFA) Short Chain Fatty Acid concentrations were calculated according to Getachew et al 2002), Microbial Biomass Production (MCP) and Efficiency Of Microbial Biomass Production (EMP) were calculated according to (Blümmel et al 1997) as:

- $\mathrm{ME}(\mathrm{mJ} / \mathrm{kg} \mathrm{DM})=2.20+0.136 \mathrm{GP}+0.057 \mathrm{CP}$ (\%),

- $\mathrm{OMD}=14.88+0.889 \mathrm{GP}+4.5 \mathrm{CP}(\%)+$ 0.0651 ash (\%), 
- $\quad$ SCFA $(\mathrm{mmol} / 200 \mathrm{mg} \mathrm{DM})=-0.00425+0.0222$

* GP

- $\quad M C P(\mathrm{mg} / \mathrm{g} \mathrm{DM})=\mathrm{mg} \mathrm{dDM}-\mathrm{GP}{ }^{\star} 2.2$

- $\left.\quad E M P=\left(m g d D M-G P^{*} 2.2\right)\right) / m g D M D$

Where GP is net GP in $\mathrm{mL}$ from $200 \mathrm{mg}$ of dry sample after $24 \mathrm{~h}$ of incubation, $2.2 \mathrm{mg} / \mathrm{mL}$ is a stoichiometric factor that expresses $\mathrm{mg}$ of $\mathrm{C}, \mathrm{H}$, and $O$ required for the SCFA gas associated with production of $1 \mathrm{~mL}$ of gas.

After $24 \mathrm{hr}$ of incubation, the filtrated rumen liquor for each sample was subjected for further investigation. The $\mathrm{pH}$ of rumen fluid was measured using $\mathrm{pH}$ meterpen and quantitative analysis of ammonia concentration was carried out by Nesler method modified by (Szumacher-Strabel et al 2002), total volatile fatty acids (TVFA's) was determined according to (John et al, 1957).

\section{Gas production calculation}

After 24 hours gas production was calculated as followed:

- GPDM= total gas production $(\mathrm{ml}) /$ substrate $\mathrm{DM}(\mathrm{g})$

- $\mathrm{GPdDM}=$ total gas production $(\mathrm{ml}) /$ substrate $\mathrm{dDM}(\mathrm{g})$

- $\mathrm{GPOM}=$ total gas production $(\mathrm{ml}) /$ substrate $\mathrm{OM}(\mathrm{g})$

- GPNDF = total gas production $(\mathrm{ml}) /$ substrate $\operatorname{NDF}(\mathrm{g})$

- GPADF = total gas production $(\mathrm{ml}) /$ substrate ADF $(g)$

- GPdNDF = total gas production $(\mathrm{ml}) /$ substrate dNDF $(g)$

- $\quad$ GPdADF = total gas production $(\mathrm{ml}) /$ substrate dADF $(g)$

\section{Chemical analysis of feed ingredients}

yellow corn, untreated and ensiled DPC were analyzed for DM and ash, (CF) Crude fiber, Crude protein (CP) (Nitrogen $x$ 6.25) and ether extract (EE) contents according to (AOAC, 2005). Neutral detergent fiber (NDF), acid detergent fiber (ADF) and (ADL) acid detergent lignin contents were analyzed sequentially (Van Soest et al 1991) using the Ankom ${ }^{200}$ Fibre Analyzer for NDF and ADF and thereafter soaking the residual with $72 \%$ sulfuric acid for 3 hours.. The NDF content was analyzed with 2 additions of heat-stable $\alpha$-amylase and $1: 1 \mathrm{~g}$ sodium sulfite per $\mathrm{g}$ sample in the neutral detergent solution. NDF and ADF are expressed inclusive of residual ash and hemicellulose and cellulose calculated from NDF, ADF and ADL values.
Non-fiber carbohydrate (NFC) was calculated according to the following formula:

NFC $(\%)=100-(\% N D+\% C P+\%$ fat $+\%$ ash $)$ (NRC, 2001).

\section{Statistical analysis}

The data of In vitro degradability and fermentation parameters were statistically analyzed according to statistical analysis system User's Guide, (S.A.S., 2004). Separation among means was carried out by using Duncan Multiple test, (Duncan, 1955). The following model was used:

$$
Y_{i j}=\mu+S_{i}+\alpha_{i j}
$$

Where: $Y \mathrm{ij}=$ the observation of the model, $\mu=$ General mean common element to all observation, $\mathrm{Si}=$ the effect of $\mathrm{i}$ the treatment, and $\alpha \mathrm{ij}=$ the effect of error.

\section{RESULTS AND DISCUSSION}

\section{Chemical composition}

Comparing between corn grain and date press cake (DPC) in chemical composition shows that they are similar in most components except fiber. Note that the ratio of total crude fiber in the DPC is about $14.86 \%$, but in the corn grain it was $2.30 \%$, resulting in an increase in the percentage of each of the NDF, ADF and ADL content in DPC compared to the corn grain Table (1).

The data of Table (1) showed comparable values of chemical composition due to effect of ensiling DPC with Exogenous enzyme with or without adding urea and exogenous enzyme supplementation in this connection Nsereko et al (2002) reported that, exogenous fibrolytic enzymes may ameliorate the nutritive value of food by-products due to enhanced attachment by rumen microorganisms. Therefore, in this study some enzymatic products such as ZAD 1 and ZAD 2 were used as dietary supplements with DPC to improve fiber digestion in it. Therefore, it is possible to improve the nutritional value of the DPC by using some additives such as enzymes or urea or mixing them.

\section{Rumen basic parameters}

Limited data are available about the effect of DPC on ruminal fermentation activity and ruminal microorganisms, moreover to its modes of action and optimal concentrations. 
Table 1. Chemical analysis between corn, Date press cake and treated Date press cake before and after ensiling.

\begin{tabular}{|c|c|c|c|c|c|c|c|c|c|c|c|c|}
\hline \multirow{2}{*}{ Items } & \multirow{2}{*}{ Corn } & \multirow{2}{*}{ DPC } & \multicolumn{7}{|c|}{ Ensiled DPC with } & \multicolumn{5}{|c|}{ Supplemented DPC with } \\
\cline { 5 - 12 } & & & ZAD1 & ZAD2 & $\begin{array}{c}\text { ZAD1+ } \\
\text { urea }\end{array}$ & $\begin{array}{c}\text { ZAD2+ } \\
\text { urea }\end{array}$ & urea & ZAD1 & ZAD2 & $\begin{array}{c}\text { ZAD1+ } \\
\text { urea }\end{array}$ & ZAD2+urea & urea \\
\hline MI & 11.65 & 22.3 & 57.9 & 57.5 & 57.3 & 57.4 & 57.2 & 57.4 & 57.7 & 53.1 & 57.6 & 66.1 \\
DM & 88.35 & 77.7 & 42.1 & 42.5 & 42.7 & 42.6 & 42.8 & 42.6 & 42.3 & 46.9 & 42.4 & 33.9 \\
OM & 98.84 & 98 & 97.4 & 97.4 & 97.3 & 97.5 & 97.6 & 97.7 & 97.8 & 97.6 & 97.5 & 97.2 \\
ASH & 1.16 & 1.99 & 2.61 & 2.65 & 2.75 & 2.53 & 2.4 & 2.35 & 2.2 & 2.43 & 2.5 & 2.78 \\
EE & 6.23 & 1.5 & 2 & 1.9 & 1.6 & 1.9 & 1.8 & 2.2 & 1.8 & 1.8 & 2.2 & 1.7 \\
CP & 10.57 & 10.5 & 8.64 & 8.91 & 13 & 12.8 & 14.5 & 10.5 & 12.6 & 14 & 14.3 & 14.2 \\
CF & 2.3 & 14.9 & 15.9 & 15.1 & 15.7 & 15.8 & 15 & 14.7 & 14.6 & 15.3 & 14.4 & 14.5 \\
NDF & 25.71 & 48 & 51 & 49.3 & 50.3 & 49.8 & 48.9 & 46.6 & 46.9 & 47.2 & 47.2 & 48 \\
ADF & 7.26 & 36.7 & 39.7 & 40.8 & 39.6 & 39.2 & 38.3 & 35.9 & 36.1 & 36.2 & 36.2 & 36.9 \\
ADL & 3.31 & 25.6 & 27.7 & 28.1 & 28 & 27.7 & 26.5 & 25.1 & 24.4 & 24.7 & 25.1 & 23.8 \\
Lignin & 2.99 & 25.3 & 27.35 & 27.68 & 27.72 & 27.35 & 26.2 & 24.86 & 24.06 & 24.37 & 24.79 & 23.47 \\
Cellulose & 3.96 & 11.1 & 12 & 12.7 & 11.6 & 11.6 & 11.8 & 10.7 & 11.8 & 11.5 & 11.1 & 13.1 \\
hemic & 18.44 & 11.3 & 11.33 & 8.5 & 10.64 & 10.57 & 10.6 & 10.78 & 10.78 & 11 & 10.97 & 11.07 \\
NFE & 71.19 & 71.2 & 70.8 & 71.4 & 66.9 & 66.9 & 66.4 & 70.3 & 68.8 & 66.5 & 66.5 & 67 \\
NFC & 48.94 & 40.1 & 38.4 & 39.9 & 35.1 & 35.5 & 34.8 & 40.6 & 38.7 & 37 & 36.3 & 36.2 \\
\hline
\end{tabular}

DPC , date press cake - MI, Moisture - DM , Dry matter - OM , Organic matter - EE ,Ether extract - CP, Crude protein - CF, Crude fiber - NDF ,Neutral detergent fiber - ADF ,Acid detergent fiber - ADL ,Acid detergent lignin - NFE ,Nitrogen free extract - NFC ,Non-fibrous carbohydrate

Volatile fatty acids are the ultimate product of microbial fermentation in the rumen and they are the main source of metabolizable energy for ruminants (Van Soest, 1982). Although, the data of Table (2) showed no significant differences in total VAF concentrate among the different incubated samples after $24 \mathrm{~h}$, it could be notice that DPC was higher total VFA's; concentrate compared to yellow corn by about $18.64 \%$. This may be due to the higher NFC as well as the lower CF recorded for corn compared to DPC. Also, it is interest to note that supplementing DPC with urea only led to decrease total VFA's compared to DPC untreated and un supplemented by about $26.21 \%$.

It is agreed that ammonia plays a central role in the rumen nitrogen metabolism; it gives an indication of protein degradability. Ammonia concentration was increased significantly with the treatments that have urea and this is logical because the urea is highly degradable and led to fast replace of ammonia in the rumen liquor (Chalupa, 1968).
Concerning ammonia concentration the ensiled DPC with ZAD2 and urea and the supplemented DPC with ZAD2 and urea and DPC supplemented with urea recorded significant $(P=0.049)$ increase in ammonia concentration compared to the control DPC (without any treatment), this may be due to effect of urea addition. On the other head, all the other experimental treatment recorded slightly higher ammonia concentration compared to DPC. These results may be due to the fact that ZAD complex contains fibrolytic enzyme and thus provides the activity of microflora, which works to break the urea (Togtokhbayar et al 2015).

Results of $\mathrm{pH}$ value in the DPC, ZAD1 and ZAD2 without ensiling were lower $(P<0.05)$ than other treatments. Also, it was observed that the $\mathrm{pH}$ value was highest $(P>0.05)$ with the ensiling treatments. The $\mathrm{pH}$ value was increased with the ensiling groups because the ensiling provides the activity of micro flora (Beauchemin and Yang, 2005). 

of date press cake

It is interest to note that all values were out of the normal range, which were very low and ranged from 4.69 to 4.90 . This may be due to the incubated samples contained high level of easy fermented carbohydrate NFE or NFC as well as low level of CP Table (1), consequently increase total VFA's formation and led to decrease $\mathrm{pH}$ values.

Table 2. Effect of ensiling and/or exogenous fibrolytic enzyme supplementation of date press cake on Rumen basic parameters.

\begin{tabular}{|c|c|c|c|c|}
\hline \multicolumn{2}{|r|}{ Items } & $\mathrm{PH}$ & $\mathrm{NH} 3$ & TVFA's \\
\hline \multicolumn{2}{|r|}{ Corn } & $4.69^{\mathrm{e}}$ & $6.63^{\mathrm{abc}}$ & 5.37 \\
\hline \multicolumn{2}{|r|}{$\mathrm{DPC}$} & $4.88^{\mathrm{ab}}$ & $4.34^{\mathrm{e}}$ & 6.6 \\
\hline \multirow{5}{*}{ 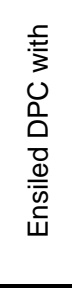 } & ZAD1 & $4.78^{\mathrm{bcd}}$ & $5.93^{\mathrm{abc}}$ & 6.67 \\
\hline & ZAD2 & $4.81^{b c d}$ & $6.02^{\mathrm{abc}}$ & 6.77 \\
\hline & $\begin{array}{c}\text { ZAD1 + } \\
\text { urea }\end{array}$ & $4.92^{a}$ & $6.89^{\mathrm{abc}}$ & 7.1 \\
\hline & $\begin{array}{c}\text { ZAD2 + } \\
\text { urea }\end{array}$ & $4.90^{\mathrm{a}}$ & $7.53^{\mathrm{ab}}$ & 6.17 \\
\hline & Urea & $4.88^{\mathrm{ab}}$ & $5.96^{\mathrm{abc}}$ & 6.27 \\
\hline \multirow{5}{*}{$\begin{array}{l}0 \\
0 \\
0 \\
0 \\
\frac{0}{1} \\
\frac{0}{0} \\
\frac{1}{3} \\
\frac{1}{3} \\
\frac{0}{0} \\
\frac{0}{3} \\
\omega\end{array}$} & ZAD1 & $4.71^{\mathrm{e}}$ & $4.66^{\mathrm{bc}}$ & 6.17 \\
\hline & ZAD2 & $4.72 d^{e}$ & $5.83^{\mathrm{abc}}$ & 7.1 \\
\hline & $\begin{array}{c}\text { ZAD1 + } \\
\text { urea }\end{array}$ & $4.85^{\mathrm{abc}}$ & $6.69^{\mathrm{abc}}$ & 6.2 \\
\hline & $\begin{array}{c}\text { ZAD2 + } \\
\text { urea } \\
\end{array}$ & $4.87^{\mathrm{ab}}$ & $7.74^{\mathrm{a}}$ & 7.27 \\
\hline & & $4.87^{\mathrm{ab}}$ & $7.29^{a b}$ & 4.87 \\
\hline \multicolumn{2}{|r|}{$S E$} & 0.02 & 0.56 & 0.8 \\
\hline \multicolumn{2}{|c|}{ P.Value } & 0.0001 & 0.0049 & 0.6544 \\
\hline
\end{tabular}

DPC, Date press cake-SE, Standard error of meanTGP, Total gas production - $\mathrm{NH}_{3}$, Ammonia mmol/l TVFA's, Total volatile fatty acids.

\section{Rumen degradability}

There were no significant differences in the values of DMD between the different treatments but the highest values $(P>0.05)$ were recorded for the treatments supplemented with ZAD2 with or without ensiling and DPC supplemented with ZAD1.

Ensiling DPC with exogenous enzyme and with or without urea or supplementation with the same treatments led to slightly improve in OM degradability except the DPC supplemented with ZAD1and ZAD2 which slightly decreased OM degradability compared to untreated DPC Table (3), more over the OM degradability for corn sample was higher than all of the other treatments.

Also, NDF and ADF degradability for corn sample were significantly higher than the other experimental treatments. However, they had no significant different among the other treatments Table (3).

These results may be due to the profile of the soluble carbohydrates in the DPC that work to increase the micro flora activity (Hoover and Stokes, 1991). In the case of NDFD and ADFD have achieved the highest values with the corn grains because the ratio of total fiber in the corn grains very few compared to DPC, which gives the opportunity for micro flora to analyze this fiber better. It is also noted that the low fiber ratio in corn grains was the indirect cause of increasing the OMD compared to other treatments.

Table 3. Effect of ensiling and/or exogenous fibrolytic enzyme supplementation of date press cake on rumen degradability.

\begin{tabular}{|c|c|c|c|c|c|}
\hline \multicolumn{2}{|r|}{ Items } & DMD & OMD & NDFD & ADFD \\
\hline \multicolumn{2}{|r|}{ Corn } & 44.67 & $57.05^{\mathrm{a}}$ & $62.49^{a}$ & $65.85^{a}$ \\
\hline \multicolumn{2}{|r|}{ DPC } & 55.53 & $49.09^{\mathrm{bcd}}$ & $33.30^{\mathrm{b}}$ & $37.47^{b}$ \\
\hline \multirow{5}{*}{$\begin{array}{l}\frac{5}{3} \\
0 \\
0 \\
0 \\
0 \\
0 \\
\frac{0}{\bar{w}} \\
\bar{w}\end{array}$} & ZAD1 & 52.99 & $50.36^{b c}$ & $33.77^{b}$ & $33.40^{b}$ \\
\hline & ZAD2 & 58.22 & $50.37^{b c}$ & $32.15^{\mathrm{b}}$ & $38.50^{b}$ \\
\hline & ZAD1 + urea & 57.48 & $53.18^{b}$ & $33.17^{b}$ & $33.80^{\mathrm{b}}$ \\
\hline & ZAD2 + urea & 57.63 & $52.63^{b}$ & $32.98^{b}$ & $35.33^{b}$ \\
\hline & urea & 56.82 & $50.80^{\mathrm{bc}}$ & $33.15^{b}$ & $37.23^{b}$ \\
\hline \multirow{5}{*}{ 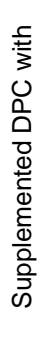 } & ZAD1 & 58.5 & $45.81^{d}$ & $33.91^{b}$ & $36.20^{b}$ \\
\hline & ZAD2 & 57.97 & $48.17^{c d}$ & $31.70^{b}$ & $40.00^{b}$ \\
\hline & ZAD1 + urea & 51.95 & $57.02^{\mathrm{a}}$ & $28.41^{b}$ & $36.90^{b}$ \\
\hline & ZAD2 + urea & 55.42 & $52.49^{b}$ & $31.60^{b}$ & $36.90^{b}$ \\
\hline & urea & 55.43 & $49.97^{\mathrm{bc}}$ & $33.35^{\mathrm{b}}$ & $36.03^{b}$ \\
\hline \multicolumn{2}{|r|}{ SE } & 3.1 & 4.54 & 2.98 & 2.3 \\
\hline \multicolumn{2}{|r|}{ P.Value } & 0.165 & 0.0497 & 0.0001 & 0.0001 \\
\hline
\end{tabular}

DPC, Date press cake -SE, Standard error of mean DMD ,Dry Matter digestibility - NDFD ,Neutral detergent fiber digestibility - ADFD, Acid detergent fiber digestibility- OMD ,Organic Matter Digestibility.

\section{Rumen gas production}

Gas production is a good indicator of microbial ferment ability, digestibility and rumen protein pro- 
duction (Salem et al 2014). The data of Table (4) showed that total gas production per $\mathrm{g} D M$, dMD, NDF and ADF were significantly higher than these values of DPC without any treatment. Ensiling DPC or supplementation with or without exogenous enzyme and urea cause great improvement in gas production per g DM, which significant improvement in GP/DM for the treated DPC compared to DPC without treatment (control) except for DPC ensiled or supplemented with ZAD1 and that supplemented with urea similar trends were observed for GPNDF, ADF and OM.

The level of total gas production in in vitro fermentation depends on the composition of nutrient content such as (plant cell walls, starch, carbohydrates, protein), presence of inhibitor for gas pro- duction (poly ethylene glycol, condensed tannins), the quality of diet provided to ruminant and the fermentation activity of micro flora in the rumen fluid (Kara, 2015a) and (Kara et al 2015b). It has been shown that exogenous fibrolytic enzymes could potentially improve fiber degradation through a hydrolytic action prior to feeding or in vitro incubation (Giraldo et al 2004) and (Elghandour et al 2013). So the insignificant improvement in the gas values with ZAD compared to the DPC was due to the presence of enzymes. The result of the GPOM gave another boost to explain the possibility of using DPC alone or with some enzymes without the ensiling process as an alternative to corn grains in ruminants feed.

Table 4. Effect of ensiling and/or exogenous fibrolytic enzyme supplementation of date press cake on gas production.

\begin{tabular}{|c|c|c|c|c|c|c|c|c|}
\hline \multicolumn{2}{|r|}{ items } & GPDM & GPdMD & GPOM & GPNDF & GPNDF & GPADF & GPADF \\
\hline \multicolumn{2}{|r|}{ Corn } & $126.13^{a}$ & $319.46^{a}$ & $112.74^{\mathrm{abc}}$ & $433.50^{\mathrm{a}}$ & $741.50^{\mathrm{ab}}$ & $1534.16^{a}$ & $764.60^{\mathrm{ab}}$ \\
\hline \multicolumn{2}{|r|}{ DPC } & $104.97^{\mathrm{bcd}}$ & $189.03^{b}$ & $104.93^{\mathrm{abc}}$ & $214.42^{\mathrm{cd}}$ & $651.04^{b}$ & $280.37^{b c}$ & $748.50^{\mathrm{ab}}$ \\
\hline \multirow{5}{*}{$\begin{array}{l}\text { F } \\
3 \\
0 \\
0 \\
0 \\
0 \\
0 \\
\frac{d}{\omega} \\
\frac{0}{4}\end{array}$} & ZAD1 & $103.92^{\mathrm{cd}}$ & $196.39^{\mathrm{ab}}$ & $104.23^{b c}$ & $199.06^{d}$ & $590.84^{b}$ & $255.90^{c}$ & $767.06^{\mathrm{ab}}$ \\
\hline & ZAD2 & $114.12^{\mathrm{abcd}}$ & $196.36^{\mathrm{ab}}$ & $114.81^{\mathrm{abc}}$ & $226.81^{\mathrm{bcd}}$ & $706.49^{\mathrm{ab}}$ & $274.10^{\text {bc }}$ & $712.05^{b}$ \\
\hline & ZAD1 + urea & $121.30^{\mathrm{ab}}$ & $211.10^{\mathrm{ab}}$ & $121.75^{\mathrm{a}}$ & $235.56^{\mathrm{bc}}$ & $711.37^{\mathrm{ab}}$ & $298.82^{b c}$ & $885.65^{\mathrm{ab}}$ \\
\hline & ZAD2 + urea & $119.96^{\mathrm{abc}}$ & $208.12^{\mathrm{ab}}$ & $120.31^{\mathrm{ab}}$ & $235.51^{b c}$ & $714.65^{\mathrm{ab}}$ & $299.01^{b c}$ & $848.14^{\mathrm{ab}}$ \\
\hline & urea & $112.20^{\mathrm{abcd}}$ & $197.49^{\mathrm{ab}}$ & $111.68^{\mathrm{abc}}$ & $222.90^{\mathrm{bcd}}$ & $674.76^{\mathrm{ab}}$ & $284.74^{\mathrm{bc}}$ & $768.06^{\mathrm{ab}}$ \\
\hline \multirow{5}{*}{ 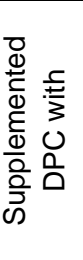 } & ZAD1 & $99.75^{d}$ & $170.42^{b}$ & $100.76^{c}$ & $211.00^{\mathrm{cd}}$ & $621.55^{b}$ & $274.42^{b c}$ & $756.51^{\mathrm{ab}}$ \\
\hline & ZAD2 & $106.13^{\mathrm{bcd}}$ & $183.20^{b}$ & $106.87^{\mathrm{abc}}$ & $222.76^{\mathrm{bcd}}$ & $707.69^{\mathrm{ab}}$ & $289.21^{b c}$ & $724.50^{\mathrm{ab}}$ \\
\hline & ZAD1 + urea & $120.65^{\mathrm{abc}}$ & $232.58^{\mathrm{ab}}$ & $121.42^{\mathrm{a}}$ & $251.18^{b}$ & 885.19ab & $327.57^{b}$ & $891.75 a$ \\
\hline & ZAD2 + urea & $114.43^{\mathrm{abcd}}$ & $207.02^{\mathrm{ab}}$ & $115.29^{a b c}$ & $238.33^{b c}$ & $756.90^{\mathrm{ab}}$ & $310.53^{b c}$ & $842.51^{\mathrm{ab}}$ \\
\hline & urea & $106.67^{\mathrm{bcd}}$ & $192.76^{\mathrm{ab}}$ & $107.23^{\mathrm{abc}}$ & $217.19^{\text {bcd }}$ & $653.14^{\mathrm{b}}$ & $282.32^{b c}$ & $786.37^{\mathrm{ab}}$ \\
\hline \multicolumn{2}{|r|}{ SE } & 3.35 & 25.54 & 3.35 & 7.01 & 43.05 & 11.07 & 33.87 \\
\hline \multicolumn{2}{|c|}{ P. value } & 0.0001 & 0.0483 & 0.001 & 0.0001 & 0.0114 & 0.0001 & 0.0092 \\
\hline
\end{tabular}

DPC ,Date press cake - SE ,Standard error of mean - GPDM ,Gas Production in Dry Matter - GPdMD ,Gas Production in Dry Matter Digestibility - GPOM ,Gas Production in Organic Matter - GPNDF ,Gas Production in Acid detergent fiber - GPNDFD ,Gas Production in Neutral detergent fiber digestibility - GPADF ,Gas Production in Acid detergent fiber GPADFD , Gas Production in Acid detergent lignin digestibility.

\section{Efficiency of rumen microbial activity}

The data of Table (5) showed that metabolizable energy (ME) and short chain fatty acids (SCHFA) were increased $(p<0.05)$ with corn sample more than DPC treatment, while microbial biomass production (MP) and efficiency of microbial biomass production (EMP) were increased $(p<0.05)$ with DPC treatment compared to corn treatment Table (6). On the other hand, ME and SCHFA values were not significantly different between corn treatment and DPC supplemented with $Z A D 1+U, Z A D 2+U$ with or without ensiling and ZAD2 without ensiling. The significant increase in both MP and EMP with DPC were a logical consequence of increasing TVFA, DMD and GP with the same treatment. 

of date press cake

These results were consistent with a previous study of (Zadeh et al 2015) where they found that increase synthesis of microbial protein (MP) in rumen when the animal feed with different levels of discarded dates.

Table 5. Effect of ensiling and/or exogenous fibrolytic enzyme supplementation of date press cake on estimating ruminal microbial efficiencies.

\begin{tabular}{|c|c|c|c|c|c|}
\hline \multicolumn{2}{|r|}{ items } & $\begin{array}{c}\mathrm{ME} \\
(\mathrm{mJ} / \mathrm{kg} \\
\mathrm{DM}) \\
\end{array}$ & $\begin{array}{c}\text { MCP } \\
(\mathrm{mg} / \mathrm{g} \\
\mathrm{DM}) \\
\end{array}$ & EMP & $\begin{array}{c}\text { SCHFA } \\
(\mathrm{mmol} / 200 \\
\mathrm{mg} \mathrm{DM})\end{array}$ \\
\hline \multicolumn{2}{|r|}{ Corn } & $4.04^{\mathrm{a}}$ & $93.28^{\mathrm{C}}$ & $0.49^{d}$ & $0.56^{a}$ \\
\hline \multicolumn{2}{|r|}{$\mathrm{DPC}$} & $3.18^{\mathrm{bc}}$ & $128.74^{\mathrm{ab}}$ & $0.58^{\mathrm{ab}}$ & $0.46^{\mathrm{bcd}}$ \\
\hline \multirow{5}{*}{ 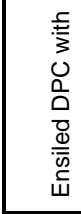 } & ZAD1 & $2.98^{\mathrm{C}}$ & $118.91^{\mathrm{abc}}$ & $0.57^{\mathrm{abc}}$ & $0.46^{\mathrm{cd}}$ \\
\hline & ZAD2 & $3.02^{c}$ & $130.57^{\mathrm{a}}$ & $0.57^{\mathrm{abc}}$ & $0.50^{\mathrm{abcd}}$ \\
\hline & ZAD1+ urea & $3.67^{a b c}$ & $120.99^{\mathrm{abc}}$ & $0.54^{\text {bcd }}$ & $0.54^{\mathrm{ad}}$ \\
\hline & ZAD2+ urea & $3.62^{\mathrm{abc}}$ & $123.26^{\mathrm{ab}}$ & $0.54^{\text {bcd }}$ & $0.53^{\mathrm{abc}}$ \\
\hline & urea & $3.79^{\mathrm{abc}}$ & $125.99^{\mathrm{ab}}$ & $0.57^{\mathrm{abc}}$ & $0.49^{\mathrm{abcd}}$ \\
\hline \multirow{5}{*}{ 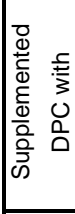 } & ZAD1 & $3.07^{\circ}$ & $146.64^{\mathrm{a}}$ & $0.62^{\mathrm{a}}$ & $0.44^{d}$ \\
\hline & ZAD2 & $3.44^{\mathrm{abc}}$ & $138.07^{\mathrm{a}}$ & $0.61^{\mathrm{ab}}$ & $0.47^{\mathrm{bcd}}$ \\
\hline & ZAD1+ urea & $3.95^{\mathrm{ab}}$ & $101.07^{\mathrm{bc}}$ & $0.49^{\mathrm{cd}}$ & $0.53^{\mathrm{abc}}$ \\
\hline & ZAD2+ urea & $3.82^{\mathrm{abc}}$ & $119.86^{\mathrm{abc}}$ & $0.54^{\mathrm{bcd}}$ & $0.50^{\mathrm{abcd}}$ \\
\hline & urea & $3.71^{a b c}$ & $125.81^{\mathrm{ab}}$ & $0.58^{\mathrm{ab}}$ & $0.47^{\mathrm{bcd}}$ \\
\hline \multicolumn{2}{|r|}{$S E$} & 0.17 & 5.44 & 0.02 & 0.01 \\
\hline \multicolumn{2}{|r|}{ P.Value } & 0.0004 & 0.0001 & $<.0001$ & $<.0001$ \\
\hline
\end{tabular}

DPC, Date press cake - SE, Standard error of mean ME, Metabolizable Energy - MP, Metabolizable Protein EMP, Efficiency of Microbial Biomass Production SCHFA, Short Chain Fatty Acids.

\section{CONCLUSION}

The current in vitro study indicated that using of DPC, ZAD1 or ZAD2 were analogous to the results of corn grains. Moreover, the existence or absence of the ensiling process did not have a clear effect on rumen activity. However, further work is recommended on the use of DPC in in vivo studies.

\section{REFERENCES}

AOAC, 2005. Official Methods of Analysis of AOAC International. $18^{\text {th }}$ Ed. Published by AOAC International Gaithersburg; Maryland; USA.

Barreveld, W.H., 1993. Date palm products. Food and Agricultural Organization of the United Nations. Agricultural Service, Bull., 101. Rome, Italy.

Beauchemin, K.A. and Yang W.Z., 2005. Effects of Physically Effective Fiber on Intake, Chewing
Activity, and Ruminal Acidosis for Dairy Cows Fed Diets Based on Corn Silage. J. of Dairy Sci., 88(6), 2117-2129.

Blummel, M., Steingab H. and Becker K., 1997. The relationship between in vitro gas production, in vitro microbial biomass yield and ${ }^{15} \mathrm{~N}$ incorporation and its implications for the prediction of voluntary feed intake of roughages. British J. of Nutr., 77, 911-921.

Boudechiche, L., Araba A. and Ouzrout, R., 2010. Influence of date waste supplementation of ewes in late gestation on the performance during lactation. Livest. Res. Rural Dev., 22(3), 51-58.

Chalupa, W., 1968. Problems in Feeding Urea to Ruminants. J. of Anim. Sci., 27, 207-219.

Duncan, D.B., 1955. Multiple range and multiple F-tests. Biomet. 11, 1-42.

Elghandour M.M.Y., Salem A.Z.M., Ronquillo M, Bórquez J.L., Gado H.M., Odongo N.E. and Peñuelas C.G., 2013. Effect of exogenous enzymes on in vitro gas production kinetics and ruminal fermentation of four fibrous feeds. Animal Feed Sci. \& Techn., 179, 46-53.

Getachew, G., Makkar H.P.S. and Becker K., 2002. Tropical browses: contents of phenolic compounds, in vitro gas production and stoichiometric relationship between short chain fatty acid and in vitro gas production. The Journal of Agric. Sci., 139(3), 341-352.

Giraldo L.A., Ranilla, M.J., Tejido, M.L. and Carro M.D., 2004. Effects of enzyme application method on the in vitro rumen fermentation of tropical forages. J. of Anim. Feed Sci., 13, 6366.

Hoover, W.H. and Stokes S.R., 1991. Balancing Carbohydrates and Proteins for Optimum Rumen Microbial Yield. J. of Dairy Sci., 74, 3630-3644.

John, A., Barnett G. and Reid R.L. 1957. Studies on the production of volatile fatty acids from grass by rumen liquor in an artificial rumen: II. The volatile fatty acid production from dried grass. J. of Agric. Sci., 49(2), 171-179.

Kara, K., 2015a. In vitro methane production and quality of corn silage treated with maleic acid. Ital. J. Anim. Sci., 14, 718-722.

Kara K.B.K., Guclu E. and Baytok. 2015b. Comparison of nutrient composition and antimethanogenic properties of different Rosaceae species. J. Anim. Feed Sci., 24, 308-314.

Menke, K.H. and Steingass. 1988. Estimation of the energetic feed value obtained from chemical analysis and gas production using rumen fluid. Anim. Res. Dev., 28, 7-55. 
N.R.C, 2001. Nutrient Requirements of Dairy Cattle, $7^{\text {th }}$ Revised Ed. National Academy Press, Washington, DC, USA.

Nsereko V.L., Beauchemin K.A., Morgavi, D.P., Rode, L.M., Furtado A.F. and McAllister, T.A. 2002. Effect of a Fibrolytic enzyme preparation from Trichoderma longibrachiatum on the rumen microbial population of dairy cows. Canadian J. of Microb., 48, 14-20.

Salem A.Z.M., Kholif A.E., Elghandour, M.M.Y., Hernandez, S.R., Domínguez-Vara, I.A. and Mellado M., 2014. Effect of increasing levels of seven tree species extracts added to a high concentrate diet on in vitro rumen gas output. Anim. Sci. J., 85, 853-860.

SAS, 2004. Statistical Analysis Systems. Version 9.2; SAS Institute; Cary; NC.

Szumacher-Strabel, M., Potkariski, A., Kowalczyk J., Cieslak, A., Czauderna, M., Gubala A. and Jedroszkowiak, P., 2002. The influence of supplemental fat on rumen volatile fatty acid profile, ammonia and $\mathrm{pH}$ levels in sheep fed a standard diet. J. of Anim. \& Feed Sci., 11, 577-587.

Togtokhbayar, N., Cerrillo, M.A., Rodriguez, G.B., Elghandour, M.M.M.Y., Salem, A.Z.M., Urankhaich, C., Jigjidpurev, S., Odongo N.E. and Kholif, A.E., 2015. Effect of exogenous xylanase on rumen in vitro gas production and degradability of wheat straw. Anim. Sci. J., 86, 765-771.

Van Soest, P.J., 1982. Nutritional ecology of the ruminant: ruminant metabolism, nutritional strategies, the cellulytic fermentation and the chemistry of forages and plant fibers. Cornell University Press, Ithaca, New York, USA, pp. 126-127.

Van Soest, P.J., Robertson, J.B. and Lewis, B.A., 1991. Methods for dietary. Fiber, neutral detergent fiber, and non-starch polysaccharides in relation toanimal nutrition. J. Dairy Sci., 74, 3583-3597.

Zadeh, J.B., Kor, N.M. and Abedini, S. 2015. The Effects of Different Levels Discarded Dates on Synthesis of Microbial Protein in Kermani Sheep. International J. of Life Sci., 9, 45-49. 


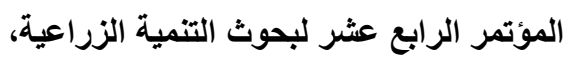

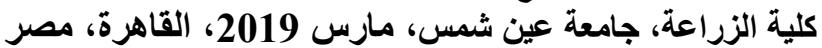

مجلد(27)، عدد (1)، عدد خاص مارس، مارس، 355-347، 2019

Website: http://strategy-plan.asu.edu.eg/AUJASCl/

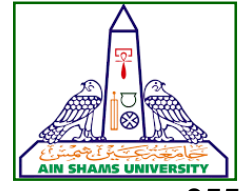

355

تأثير عملية الكمر عثى إستخدام المنتج الثانوى لصناعة دبس التمر المعامل بالانزيمات عثى نشاط الكرش معمثيا

$[32]$

\author{
محمود فهمى1 - - طارق عبدالقتاح مرسى 1'- هانى محمود جادو²- أسامة حفنى مطلوب1- \\ صبحى محمود خليف 1- نصر السيد البردينى 2

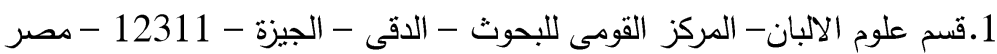 \\ 2.قسم الانتاج الحيوانى - كلية الزراعة - جامعة عين شمس - صلان. ب. 68 حدائق شبرا $11241-$ القاهرة - مصر
}

"Corresponding author: fahmymahmoud2@gamil.com

Received 12 December, 2018, $\quad$ Accepted 22 January, 2019

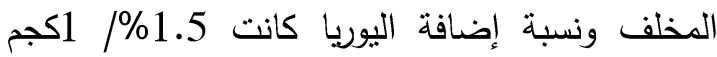

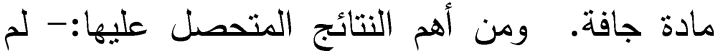

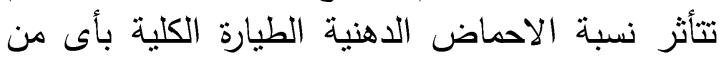

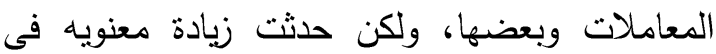

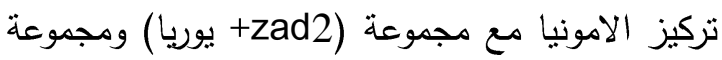

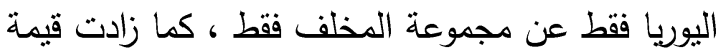

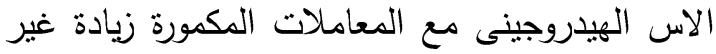

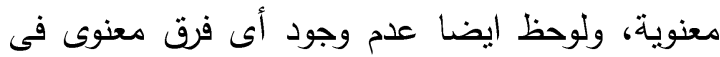
قيمة كل من المادة الجافة المهضومة والمادة العضاد العضوية

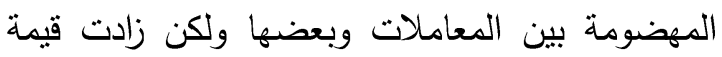
كل من NDF المهضوم و

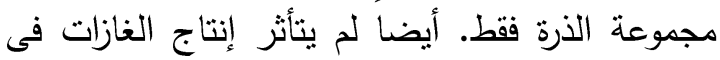
الكرش بين مجموعة الذرة ومجموعة المخلف. حققت قيمة الطاقة الممثلة والبرو تين الميكروبى المنتج زيكة ليدادة معنوية مع مجموعة المخلف مقارنة بمجموعة الذربن الذره ومن ذللك يتضح أن عملية الكمر لم تحدث أى تأثنير واضح على المخلف المعامل لتحسين تخمرات الكرش. الكلمـات الدالـه: مخلف تصنيع دبس التمر ، تخمرات الكرش معليا، انتاج الغازات بالكرش

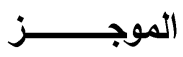

تم إجراء هذه الدراسة لتقييم تأثثر مخلف صناعة

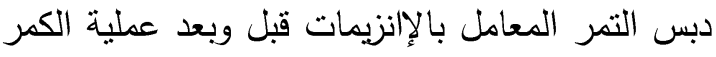

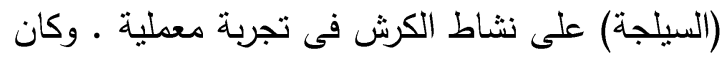
الغرض الاساسى من التجربة هو تحسين القيمة الغذائية

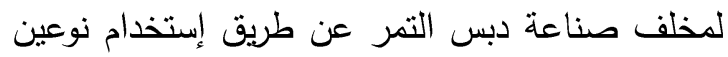

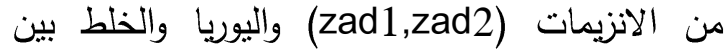
الانزيمات واليوريا معا بنسب مختلفة وأيضا إجراء عملية الكمر. وتم تقسيم التجربة الى إثنتا عشرة مجموعة هى كالتالى: مجموعة الذرة فقط، مجموعة مخلف دبس التمر فقط (بدون معاملة أو إضافة)،

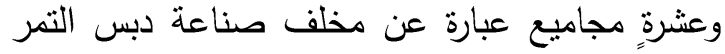

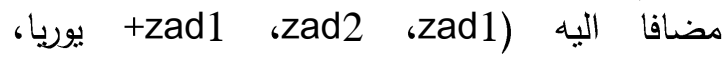
tzad2

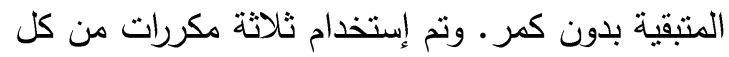

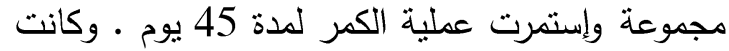
نسبة إضافة الانزيمات 2مل/ 1 كجم مادة جافة من لون وكان 